\title{
Russian Twin Studies: Colleagues, Controversies, Case Studies and Current Events
}

\author{
Nancy L. Segal' and Irina N. Senina ${ }^{2}$ \\ ' Department of Psychology, California State University, USA \\ ${ }^{2}$ Department of Biology, California State University, USA
}

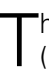
2001 honoring of Russian twin researcher, Dr. Inna V. Ravich-Shcherbo, at the Tenth International Congress on Twin Studies (ISTS), in London, brought timely recognition to an international colleague. It also marked an occasion for reflecting on the course of twin studies in Russia. Historical trends and current accomplishments are examined with an eye toward future developments. Next, the distinguished careers of Russian monozygotic twins, Drs. Alexander and Andrew Fingelkurts, exemplify twin research findings on intelligence and occupational choice, and illuminate the status of twin studies and other scientific research in their country, are told. Their life histories are followed by the initially tragic, but ultimately heartwarming, story of young twins, Max and Andy, whose physical disabilities were overcome through the efforts of an empathic war veteran. The recent Moscow Summer School, the first in a three-time lecture series, encouraged crucial academic exchange among scientific investigators and students from around the world. Final thoughts are that much can be learned and much can be accomplished, given that we continue to nurture the twin-related resources available to us.
\end{abstract}

\section{A Colleague Honored Tribute to Dr. Inna V. Ravich-Shcherbo}

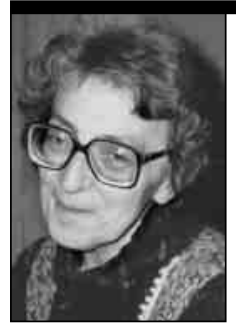

"She [RavichShcherbo] is the 'Mother of Twin Research' in Russia" (Finkelkurts, 2001). Her gift is revival of twin-based approaches to behavior, following state imposed suspension for nearly forty years. On the final day (July 7, 2001) of the Tenth International Congress on Twin Studies (ISTS), in London, a tribute was read in her honor:

Dr. Inna V. Ravich-Shcherbo is an exceptional example of an academician whose contribution cannot be evaluated only in terms of empirical achievements, but also must be viewed in terms of its impact on the history of science.

Ravich-Shcherbo started her professional career in the mid-fifties, at the end of the Stalin era. As a result of her interest in the etiology of individual differences, she came upon the field of behavioral genetics in foreign literature, which stimulated her research on the applications in Russia of family and twin methodology. RavichShcherbo investigated historical records and discovered an exciting line of research carried out by a group of Russian scientists in the late teens and early twenties under the direction of Dr. Levit, a peer of Dr. Vavilov. Among those young scientists were many whose names now are well known, including Alexander Luria. The group had established the Moscow twin registry and launched a number of studies using twin methodology. In its very brief period of existence, the group generated more than two dozen publications and then...disappeared. A number of its members, including Levit himself, perished in the Stalinist repression. The science they practiced (known in Russia as psychogenetics) was condemned. The publications were banned and hidden from scientists in the basements of libraries. The years of the dominance of the "social" paradigm in genetics and agriculture, known as "lysenkovschina," lasted well into the sixties.

In her scientific and organisational work, Ravich-Shcherbo restored and cherished this rediscovered approach. She sustained this approach despite pressure from the dominant ideology and re-introduced psychogenetics, especially twin research, to Russian science. She prepared a generation of new scientists who, once again, formed a group initially led by her, and now led by her former students. Ravich-Shcherbo's rigor, tolerance and scientific sophistication are exemplary and shine through in her research and teaching.

Address for correpsondence: Nancy L. Segal, Department of Psychology, California State University, Fullerton, CA 92834 USA. Email: nsegal@fullerton.edu 
A remarkable scientist, a true academician and a very strong person, Dr. Inna $\mathrm{V}$. Ravich-Shcherbo is responsible for the current existence of the field of twin research in Russia." (Written by Dr. Elena Grigorenko and read by Dr. Robert Plomin)

The decision to recognise Dr. RavichShcherbo arose from a meeting between Drs. Robert Plomin (Institute of Psychiatry, London) and Elena Grigorenko (Yale University and Moscow Psychological Institute of the Russian Academy of Education). Plomin explained:

I first met Ravich-Shcherbo during a visit to Moscow in the 1970s. In the late 1980s, I tried to develop a twin register in Moscow with [her]. She was an impressive scientist who persevered in science at a time when it was extremely difficult to do so in the Soviet Union. One of the people working with Ravich-Shcherbo was Elena Grigorenko. I was with Elena at a meeting in the spring 2001 and asked about Ravich-Shcherbo. In reminiscing about her long career with twin studies, Elena suggested that we should try to do something to honor her work.

Recognition of Ravich-Shcherbo coincided with my return from Russia (see below) where I had presented twin research to students and faculty at the first Moscow Summer School series. In Moscow and Zvenigorod (the summer school venue) I had opportunities to meet many of her students and colleagues from the Russian State University; unforeseen events had, unfortunately, prevented her from attending the sessions. The fact that the London tribute commended a scholar about whom I had just heard a great deal lent special significance to that moment. This was, perhaps, the start of an ISTS tradition of honoring individuals whose accomplishments override their exceptional circumstances.

\section{A Look Back}

To delve into the beginnings of twin research in Russia is to find the familiar in an unknown place. Concepts of cotwin control, twin registries, gene $\mathrm{x}$ environment interaction, even emergenesis, were present from the start (albeit, in different forms and names). Key goals, such as elucidating behavioral mechanisms and age-related changes, are recognisable and still timely.
Empirical twin work started somewhat later in Russia than in other countries, but twins' potential contributions to behavioral investigations were celebrated in international unison. On Homologous Twins, written in 1891 by the Russian scientist Miller and inspired by Galton's (1876) seminal paper, may be the first Russian work on twins (Grigorenko \& Shcherbo, 1997). Interest and activity surrounding the nature and bases of human heritable variation were clearly evident in the late1800s.

Russian twin studies began in the late 1920 's, flourished through the late 1930 s, then vanished until the late 1960s. The period of quiescence was marked by "implicit prohibition" (late 1930s), followed by explicit forbiddance (1948) (Grigorenko \& Ravich-Shcherbo, 1997). Reemergence of twin methods in the late 1960s produced an array of scientific books, papers and presentations.

Tracking twin research's ebb and flow is to follow political events in the former Soviet Union. Eugenics departments, as well as a eugenics society and journal, were established in the 1920s in the USSR, and elsewhere (Vogel \& Motulsky, 1986). This line of work was short-lived, given the opposition of eugenic goals and official MarxistLeninist principles. Many scientists, consequently, turned to plant and other non-human research. At the same time, human medical genetic studies flourished in Russia, at least for a time. The year 1929 proved pivotal in this regard, especially in the study of twins. That year saw the establishment of the Medico-Biological Institute, directed by L.E. Levit. Levit defined the Institute's main task as "the study of genetics and of those sciences closely related to genetics such as cytology, and further, of developmental mechanics and evolutionary theory as they apply to the problems of medicine, anthropology, psychology, and education" (Levit, 1935, p. 188). Over 800 twin pairs participated in interdisciplinary studies conducted by Institute staff. Unfortunately, this productive period of twin research activities proved brief.

The1930s's pronouncement of human genetics as a Nazi science, and the 1940s's Lysenkoist dismissal of genetic and evolutionary studies as dangerous to the state halted genetic investigation for twenty years (Gardner, 1957). Scientists were banished and many, like Levit, were never heard from again. Medical genetic studies lay dormant until the1960's when Lysenkoism faded. This latest era was ushered in by new textbooks and a new genetics institute, directed by N.P. Bochkov who remains active today (Vogel \& Motulsky, 1986). It is this climate into which Ravich-Shcherbo entered and prevailed.

Only a thumbnail sketch of Russia's prior twin studies is possible, given the scope of this column. Many crucial contributors and events are well described in Levit (1935), Grigorenko \& Ravich-Shcherbo (1997) and other sources. I will, however, provide a sampling of current studies of interest to readers. Levit's (1935) paper offers a superb glimpse into early twin activities, furnishing a natural starting point.

\section{A Closer Look Back}

Work at the Medico-Biological Institute is credited with having launched the science of psychogenetics in Russia (Grigorenko \& Ravich-Shcherbo, 1997). Psychogenetics, broadly defined, concerns the heritable basis of psychological characteristics. Four main areas were defined: cultural and genealogical methods; twin research designs, eugenics and public knowledge of eugenic findings; and familial transmission of psychiatric disorders.

The Medico-Biological Institute was clearly a treasure trove. A highlight was a special kindergarten for twins enabling a succession of experimental studies. Researchers paid considerable attention to the environment as a relatively neglected aspect of development. Specifically, there was concern that genetic and environmental contributions to trait variation would be affected by living conditions and the genetic composition of the population in question. Age was also seen as a neglected factor in twin investigations, given that age-related changes at the level of the individual and population may differ. Thus, efforts were made to study twin pairs of similar age (Levit, 1935).

The effects of training on performance were also emphasised. An especially intriguing co-twin control study observed 5.0 - 5.5-year-old twins completing similar tasks under different 
conditions (Grigorenko \& RavichShcherbo, 1997; Levit, 1935). Children constructed a figure from bricks by copying a figure created by the examiner. The "model method" presented a figure covered by paper, while the "element" method presented a figure in full view. Each twin participated in twelve trials over several months. Poststudy evaluations showed that the model method produced persisting changes in constructive and perceptual skills relevant to the experimental task, and to skills in other domains. In contrast, the element method failed to produce cognitive change.

Co-twin control methods were also used to evaluate treatment effects on physical and medical conditions. One co-twin from five $\mathrm{MZ}$ twin pairs concordant for rickets received ultra-violet ray exposure, a practice producing improvement. When monochorial twins were born, one infant received immunisation, while the co-twin did not (Levit, 1935). Of course, current ethical standards would disallow withholding of beneficial treatment to one twin.

Other influential work was performed by M.S. Lebedinsky in 1932 . His paper is considered 'the first fundamental Russian psychological publication with a psychogenetic content" (Grigorenko \& RavichShcherbo, 1997, p. 100). His work was somewhat controversial as it questioned some fundamental assumptions of twin methodology. Interestingly, he advocated combining twin and family designs, an approach that is popular today.

A visit to Russia from twin research's familiar friend, Bronson Price, occurred during these years. (Price is famous for 1950 and 1978 papers on prenatal influences ["primary biases"] associated $\mathrm{MZ}$ co-twin differences in development.) In looking over A.R. Luria's archives, Dr. Ravich-Shcherbo recently discovered that Price, a statistician, had worked in Luria's laboratory. She wrote the following: "He researched giftedness using the twin method and also lead the seminars. Could it be the same Bronson Price who is mentioned in your book Entwined Lives on page 319 and in other works of psychogenetics? Is it possible to find out somehow?" The answer lay just ten seconds and two feet away because, filed among my reprints, was a paper by Gordon Allen (1978) commemorating Price's career. Price had, in fact, spent time in Moscow as a fellow of the Social Science Research Council. There he became a close colleague of H.J. Müller, senior scientist at the Medico-Genetical Research Institute in Moscow from 1933-1936. Price produced a paper, "USSR notes" (Price, 1937), copyrighted, but unpublished. Sensing Ravich-Shcherbo's excitement at possibly discovering this interesting connection, I forwarded the information to her immediately.

Price's precious notes and memoirs would provide an informative take on the nature of twin research and other activities during those times. It might also resolve a curious conflict between statements made by G. Allen and M.S. Lebedinsky. Allen wrote, "The seed for the Primary Biases paper was probably sowed at the Medico-Genetical Institute in Moscow, where the importance of the mutual circulation for surviving twins was discounted" ( $p$. 95). However, Lebedinsky questioned $\mathrm{MZ}$ twins' pervasive likeness in view of prenatal circumstances linked to early and later developmental differences in both types of twins (Grigorenko \& Shcherbo, 1988). Thus, awareness of prenatal influences on MZ twins' behavior was recognised (although may not have been sufficiently considered in interpreting findings). The 100-year jubilee honoring A.R. Luria (1902-1977) is approaching (RavichShcherbo, 2001), providing an opportune time to revisit this question.

Other issues have been more readily addressed, due to the survival of some twin data. As a visiting investigator at the Institute in 1936, Sidney L. Halperin wondered if family effects on mental skills might be diminished in a culture that disparaged class structure (Halperin, 1975). He administered ability and achievement tests to 146 MZ and 155 DZ Russian twin pairs in elementary school. The fortunate preservation of these data produced a paper published forty years later. Halperin found that family environments were not less significant in 1930s Russia than in modern America.

The1930's attention to age effects on heritability was also evident in the 1970s, and beyond. Sandwiched between these years was the publication of Luria and Yudovitch's classic case study on twin boys expressing private speech. The investigators showed that separating the twins, and administering speech therapy to one co-twin led to significantly improved language skills. This study, conducted in the 1930s, was first published in the U.S.S.R. in 1956, with later printings in 1959 and 1966 in Great Britain. It seems surprising that a twin study should be published and circulated during the years that such efforts were forbidden. A possible explanation is that this work demonstrated environmental influence on language ability, even though Luria was clearly concerned with the joint effects of genes and experience.

The dynamic gene-environment balance was of great interest to RavichShcherbo. In the late 1970 s, she stressed the importance of considering the heritability of trait components (as well as traits) across developmental stages. This reasoning affected "virtually all psychogenetic studies conducted in Russia in the late 1980s and early 1990s" (Grigorenko \& Ravich-Shcherbo, 1997, p. 106). Consequently, one of Dr. RavichShcherbo's important legacies is an ongoing longitudinal twin study of behavioral development. This project has yielded seventeen doctoral dissertations.

\section{In Her Own Words}

Dr. Inna V. Ravich-Shcherbo is the link between past and present twin research in Russia. As such, her efforts importantly affect the future course of the field. Listening to her is to appreciate the genesis of her own interests in twins, and those of her country, more fully than textbook renditions will allow. In her own words:

NS: How did you become interested in twin studies? What exactly made you interested?

RS: I became interested in twins as a method for studying hereditary attributes of the human nervous system. This question (applied to animals) arose in the works of the famous Russian physiologist, I.P. Pavlov. My first student who started this work, N.F. Shliakhta (Department of Psychology at Moscow State University), studied features of the strengths of nerve processes. Others joined her later. The main results are presented in our first collection, 
Problems of the Genetic Psychophysiology of Humans, published by Nauka (Science) in 1978.

NS: What research activities did you pursue during the years that psychogenetic work was not allowed?

RS: I worked in the laboratory of one of the biggest nativist psychologists, B.N. Teplov. He was also my instructor in graduate school when I studied the attributes of the nervous system using sensory and motor electrophysiologic methods in adults and children, and in children with mental handicap.

NS: In Russia today, what is the most exciting twin study or twin research finding?

RS: Unfortunately, we have a financial situation here which makes it very hard to do much research on twins. That is why there are not many such studies. However, I think they are all very interesting, including the psychophysiologic studies, studies of twins from the first months of life (T.A. Stroganova and collaborators at the Brain Research Institute and E.A. Sergenko and collaborators, Russia Psychological Institute) and the longitudinal study of twins from pre-school to later years (M.S. Egorova and collaborators, at our institute, which is the Psychological Institute).

In the last few years, colleagues from the medical institute surveyed 135 pairs from 40 to 60 years of age, with reference to blood pressure, daily and nightly blood pressure profile, hypertension, and other measures (A.P. Saharndak, L.l. Kirichenko and collaborators). Among the earlier studies, I would note the psychophysiologic studies of T.M. Marytuina on optically caused potentials, and the work of S.B. Malykh on brain potentials associated with motion. In addition, there is the interesting work by N.V. Gavrish, S.B. Malykh and T.A. Meshkova on EEG spectral characteristics and sex differences in 6-7-year-old twin children.

NS: Do Russian twins feel special like twins in most places? Do parents of twins feel special or overwhelmed?

RS: It is hard for me to answer this question because right now I communicate with twins very little. But my impressions coincide with what my colleagues claim, namely that our twins, as a rule, do not feel they are different from others. The parents are mostly concerned with solutions for difficulties posed by life conditions arising from the birth of twins.

Note (NS): Comments by an adult Russian MZ male twin pair provided below extend this discussion.

NS: You said that twin research is part of the standard college curriculum. When did that start and what topics are covered?

RS: I started reading psychogenetics as a special course (elective) in the Department of Psychology at Moscow State University, in 1980-1982. In1994, it [psychogenetics] became a national standard for higher and professional education for specialisation in psychology. The curriculum was written by me, along with a collaborator from the faculty of psychology at Moscow State University, a candidate in psychological sciences, S.A. Isaichev, and affirmed by the instructional board of the Russian Federation of Universities. It includes the current state of modern genetics, the history and development of psychogenetics (in Russia and elsewhere), analytic methods and main results. Topics include studies of individual differences in cognitive and motor functions, psychophysiological characteristics and anomalies, and some forms of abnormal development.

NS: Explain more about the ARTS (Adult Russian Twin Study) - how did the registry get started? Is there a registry of young twins or infant twins, or plans to set them up?

RS: We developed the twin registry beginning with the first years of the laboratory's establishment. We did this by sending letters about twins to schools and kindergartens in Moscow. Some of the adult twins were also found through letters sent to schools when they were younger. The other adult twins we gathered in the1990s by posting ads in Moscow newspapers.

We do not have a twin center yet, but I am working on its establishment right now. I am hoping that this will take place - I tried it several times before, but it did not happen.

NS: Are there any well-known conjoined twin cases in your country?

RS: I know of the existence of two such pairs. Masha and Dasha Krivoshlyapova are 51 years old and live in a nursing home. Sometime ago they were studied by P.K. Anokhin and his collaborators. Ten-year-old Zita and Gita Rezahapova are another pair of conjoined twins. According to one of our newspapers, they will be separated soon by Russian and Spanish doctors. We did not study conjoined twins in my laboratory.
Note (NS): Masha and Dasha were of great scientific interest because of their unusual physical connections (Davis Chiropractic Center on-line). The twins are dicephalic, with separate upper intestines and shared lower intestine, rectum, reproductive system, digestive system and circulatory system. Their dramatically differing health patterns were initially puzzling to physicians. It is now believed that the status of their individual spinal cords and columns explains their differential susceptibilities to illnesses.

When the twins were born in 1950, their mother was informed that they had died. They had, however, been placed in an institute near Moscow for continued study. They attracted considerable public interest when their life history was documented on a national television program in Russia. They are currently patients of Dr. Lale Khankichi-Zade, a dentist associated with the Adventist Health Center in Moscow. Dr. Khankichi-Zade recently joined the International Dentist program at Loma Linda University's School of Dentistry (LLU News and Events, 2000).

Masha and Dasha say they prefer the difficulties of life as conjoined twins over the risks of surgical separation. A book about their life has recently been written in Russian, and will soon be available in English and German (BBC, on-line).

NS: Is Miller's 1891 book similar to Galton's work?

RS: Miller's work is mostly about embryonic development and post-natal maturation of twins. There is also information about twins and diseases.

NS: What is the twin research you have done that you feel is most significant?

RS: I think that the most interesting of our studies are those that tested A.R. Luria's hypothesis about possible change in the relative contributions of genetic and environmental determinants to psychological traits during development. These are the studies by T.A. Panteleeva (voluntary and nonvoluntary movement), T.N. Marytuina (optically caused potentials) and E.V. Orekhova and S.B. Malykh (readiness potentials associated with simple voluntary movement). I think that such studies might bring clarity to variation in genetic and environmental factors relevant to these behaviors. I also think that the studies of connections between genetic influence and physio- 
logic maturity are of interest. These have been completed by Stroganova and colleagues, Meshkova and Gavrish.

NS: Would you ever host an International Society of Twin Studies meeting in Russia?

RS: We have not thought yet about such a meeting, but if it will be possi- ble to establish the twin center, then we will definitely give it a thought. Thank you for the idea.

In closing:

Dear Nancy! Have I answered your questions fully? If you will need something else, please write and I will answer right away. Were you able to read my previous letter? I wish you all the best. Thank you very much for your warm wishes.

Yours, I.V. Ravich-Shcherbo

Published work contributed by the contemporary researchers cited by Dr. Ravich-Shcherbo are included in the reference section.

\section{Twin Research in Russia: Today and Tomorrow}

Twins R' Us (sia). I could not resist the prior play on words and letters (!) now conventional in the United States and elsewhere. The result is, however, an auspicious label for this section on the current status of Russian twin research.

Studies using Russian twin samples are more plentiful than I was aware (despite Ravich-Shcherbo's regret that there were few). This may be explained by their comprehensiveness (topics are varied, so reports appear in diverse books and journals) and presentation (writing is often in Russian, limiting access by international colleagues). There is clearly much to discover and appreciate. Many subjects and scientists were mentioned by Dr. Ravich-Shcherbo in her wonderful interview. I will, therefore, review some of the most recent work generated by an ongoing longitudinal behavioral development study and by the Adult Russian Twin Study (ARTS). First, the chapter outline of Dr. RavichShcherbo's (1988) book, The Role of Heredity and Environment in the Organization of Human Individuality, is presented. Elena Grigorenko graciously photocopied this work for me (even though it was written in Russian!). Translation of the complete text was prohibitive, but translation of chapter headings was not, a task left to my Russian-born co-author. This information offers a glimpse into Dr. Ravich-Shcherbo's life work:

- Analysis of quantitative traits

- Twin method

- The role of heredity and environment in EEG variability

- The nature of interpersonal change in evoked potentials
- Psychogenetic study of psychophysiological structures

- The role of genetic and environmental determinants in changes in motor functioning

- Genotype and environment in the variation of cognitive functions

- The nature of interpersonal change in temperament and personality

- (In Place of an Epilogue): Methodological problems of psychogenetics: The philosopher's view.

Table 45 from chapter 7 is reproduced in Russian (see Figure 1) and translated into English (see Figure 2). Like the beginnings of Russian twin research, it is exciting to find the familiar in an unknown place.
Recent twin studies have examined the heritability of behavioral traits, in addition to their developmental aspects. Cognition and creativity were assessed using $60 \mathrm{MZ}$ and $63 \mathrm{DZ}$ twin pairs assembled mostly from a Moscow-based population registry established by members of Dr. Ravich-Shcherbo's Psychogenetics and Individual Differences Laboratory (Grigorenko, LaBuda, \& Carter, 1992). Additional pairs were identified with the cooperation of a Leningrad twins' club and Voronezh school administrators. IQ and cognitive ability correlations for $\mathrm{MZ}$ and DZ twins were generally comparable to those reported for other twin samples (MZ: .69 to .88; DZ: .37 to $.73)$, although IQ heritability was lower than that reported elsewhere (.29 vs.

\begin{tabular}{|c|c|c|c|c|c|c|c|c|c|c|}
\hline \multirow{2}{*}{ 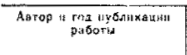 } & \multirow[t]{2}{*}{ Показа хели } & \multicolumn{2}{|c|}{4 पn:.10 пар } & \multirow[t]{2}{*}{ Bospatit } & \multicolumn{2}{|c|}{ Ma.16411xif } & \multicolumn{2}{|c|}{ Aenotinit } & \multicolumn{2}{|c|}{ Bumeate } \\
\hline & & Mz & $\mathrm{D} \%$ & & MZ & $\mathrm{Dz}$ & $M Z$ & De & $\overline{A Z}$ & $\overline{\mathrm{D} Z}$ \\
\hline D. G. Freedntzan, 1965 & 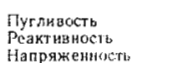 & 9 & 10 & $0-1$ roa & $=$ & $\overline{-}$ & - & $\overline{-}$ & $\begin{array}{r}3 \text { 3на } \\
3 \text { на } \\
\text { Heз1 }\end{array}$ & 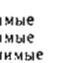 \\
\hline $\begin{array}{l}\text { H. H. Goldsmith. J. } 3 . \\
\text { Campos. } 1982\end{array}$ & $\begin{array}{l}\text { Cтрах } \\
\text { Гнев }\end{array}$ & 29 & 61 & $9 \mathrm{nec}$ & - & - & $\ldots$ & - & 0.66 & 0.46 \\
\hline A. P. Matheny, 1980 & Эмоциона ЛЬЛІОсть & $\begin{array}{c}72 \\
91\end{array}$ & $\begin{array}{l}35- \\
50\end{array}$ & $\begin{array}{l}3 \mathrm{mec} \\
5 \mathrm{mec} \\
9 \mathrm{Mec} \\
12 \mathrm{mec} \\
18 \mathrm{mec} \\
24 \mathrm{sec}\end{array}$ & $\begin{array}{l}= \\
= \\
= \\
=\end{array}$ & $\begin{array}{l}= \\
= \\
= \\
=\end{array}$ & $\begin{array}{l}= \\
= \\
= \\
= \\
=\end{array}$ & $\begin{array}{l}= \\
= \\
= \\
= \\
=\end{array}$ & $\begin{array}{l}0,77 \\
0,88 \\
0,55 \\
0,35 \\
0,43 \\
0,49 \\
0,53\end{array}$ & $\begin{array}{l}0,35^{*} \\
0,26 \\
0,10^{*} \\
0,33 \\
0,07^{*} \\
0,37 \\
0,03^{*}\end{array}$ \\
\hline $\begin{array}{l}\text { P. Fromsi, } 1974 \text { (см.: } \\
\text { A. Buss, R. Plomin, } \\
\text { 1976) }\end{array}$ & $\begin{array}{l}\text { Общая эмоцнонаяь- } \\
\text { ность } \\
\text { Cтрах } \\
\text { Г̈lев }\end{array}$ & 60 & 51 & 3.5 rosta & $\begin{array}{l}0.59 \\
0.81 \\
0.80\end{array}$ & $\begin{array}{c}0,4 \overline{3} \\
0,60 \\
-0,09^{*}\end{array}$ & $\begin{array}{l}0,29 \\
0,59 \\
0,26\end{array}$ & $\begin{array}{c}\ldots, 35^{*} \\
0,065^{*} \\
0,21\end{array}$ & $\begin{array}{l}0,47 \\
0,70 \\
0,07\end{array}$ & $\begin{array}{l}0,10^{*} \\
0,38^{*} \\
-12^{*}\end{array}$ \\
\hline A. Buss et al. 1973 & Эмоцнональность & 78 & $\Xi 0$ & 4,5 roda & 0,63 & $00^{*}$ & 0.73 & $9.90^{\circ}$ & - & - \\
\hline $\begin{array}{l}\text { S.G. Vandenberg that.. } \\
1968\end{array}$ & $\begin{array}{l}\text { Раздражнтеяьность } \\
\text { Вепьльчиость } \\
\text { Плаксивость }\end{array}$ & 35 & 39 & $0-6$ תet & $\overline{-}$ & $\underline{m}$ & $\underline{-}$ & $\begin{array}{l}- \\
\overline{-}\end{array}$ & Незн & гімые \\
\hline $\begin{array}{l}\text { R. Wilson et at.. } 1971 \\
\text { H. H. Goldsmith, }{ }^{2} 1.1 \\
\text { Gottesman, } 1981\end{array}$ & $\begin{array}{l}\text { Плаксивость } \\
\text { Разаражите.льность } \\
\text { Раздражняльность } \\
\text { Пугливость }\end{array}$ & $\begin{array}{l}95 \\
72- \\
91\end{array}$ & $\begin{array}{c}73 \\
35- \\
50\end{array}$ & $\begin{array}{l}0-6 \text { лег } \\
4 \text { года }\end{array}$ & $\bar{z}$ & $=$ & 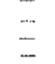 & $\overline{-}$ & $\begin{array}{l}3 \mathrm{Ha} \\
0.45 \\
0.36\end{array}$ & $\begin{array}{l}\text { Mue } \\
0.17^{*} \\
0.21\end{array}$ \\
\hline $\begin{array}{l}\text { R. Plomin. T. T. Fuch. } \\
1980\end{array}$ & Aгрессивность & $40-$ & $\begin{array}{l}28-6 \\
32\end{array}$ & 7 דع 7 & - & - & 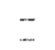 & $\overline{-}$ & $\begin{array}{l}0.38 \\
0.43\end{array}$ & 0.44 \\
\hline S. Searr. 1966. & $\begin{array}{l}\text { Беспокойство } \\
\text { Тревожность }\end{array}$ & 24 & 28 & 6 -10.лет & - & - & 0,56 & $0,03^{*}$ & - & - \\
\hline $\begin{array}{l}\text { A. P. Matheny, A }, 11 \\
\text { Dolan, } 1980\end{array}$ & Эмоннональность & 68 & 37 & $7-10$ :1ет & $-\cdots \cdot$ & - & - & - & 0.40 & $-0,11$ \\
\hline
\end{tabular}

Figure 1

Table 45 from Dr. Ravich-Shcherbo's (1988) book, The Role of Heredity and Environment in the Organization of Human Individuality. 


\begin{tabular}{|c|c|c|c|c|c|c|c|c|c|c|}
\hline \multirow[t]{2}{*}{ Author, Year } & \multirow[t]{2}{*}{ Factor } & \multicolumn{2}{|c|}{$N$ (Pairs) } & \multirow[t]{2}{*}{ Age } & \multicolumn{2}{|c|}{ Boys } & \multicolumn{2}{|c|}{ Girls } & \multicolumn{2}{|c|}{ Combined } \\
\hline & & $M Z$ & $D Z$ & & $\mathrm{M}$ & $\mathrm{DZ}$ & $M Z$ & $D Z$ & MR & $D Z$ \\
\hline D.G. Freedman, 1965 & $\begin{array}{l}\text { Fearfulness } \\
\text { Reactivity } \\
\text { Intensity }\end{array}$ & 9 & 10 & 0.1 year & & & & & $\begin{array}{l}\text { Sign } \\
\text { Sign } \\
\text { Non- }\end{array}$ & $\begin{array}{l}\text { cant } \\
\text { cant } \\
\text { ignificant }\end{array}$ \\
\hline H.H. Goldsmith, & Fright & & & & & & & & & \\
\hline J.J. Campos, 1982 & Anger & 29 & 61 & 9 months & & & & & $\begin{array}{l}.66 \\
.77\end{array}$ & $\begin{array}{l}.46 \\
.35^{*}\end{array}$ \\
\hline A.P. Matheny, 1980 & Emotionality & $\begin{array}{r}72- \\
91\end{array}$ & $\begin{array}{r}35- \\
50\end{array}$ & $\begin{array}{r}3 \text { months } \\
6 \text { months } \\
9 \text { months } \\
12 \text { months } \\
18 \text { months } \\
24 \text { months }\end{array}$ & & & & & $\begin{array}{l}.18 \\
.55 \\
.35 \\
.43 \\
.49 \\
.53\end{array}$ & $\begin{array}{l}.26 \\
.10^{*} \\
.33 \\
.07^{*} \\
.37 \\
.03\end{array}$ \\
\hline $\begin{array}{l}\text { R. Plomin, 1974; } \\
\text { also see: } \\
\text { A. Buss, R. Plomin, } \\
1976\end{array}$ & $\begin{array}{l}\text { Overall } \\
\text { Emotionality } \\
\text { Fright } \\
\text { Anger }\end{array}$ & 60 & 51 & 3.5 years & $\begin{array}{l}.59 \\
.81 \\
.80\end{array}$ & $\begin{array}{l}.45 \\
.60 \\
-.09^{\star}\end{array}$ & $\begin{array}{l}.29 \\
.59 \\
.26\end{array}$ & $\begin{array}{l}-.35^{\star} \\
.06^{\star} \\
-.21\end{array}$ & $\begin{array}{l}.47 \\
.70 \\
.57\end{array}$ & $\begin{array}{l}.10^{\star} \\
.38^{\star} \\
-.12^{\star}\end{array}$ \\
\hline $\begin{array}{l}\text { A. Buss et al., } 1973 \\
\text { S.G. Vandenberg } \\
\text { et al., } 1968\end{array}$ & $\begin{array}{l}\text { Emotionality } \\
\text { Irritability } \\
\text { Irascibility } \\
\text { Sadness }\end{array}$ & $\begin{array}{l}78 \\
35\end{array}$ & $\begin{array}{l}50 \\
39\end{array}$ & $\begin{array}{l}4.5 \text { years } \\
0-6 \text { years }\end{array}$ & .63 & $.00^{*}$ & .73 & $.20^{*}$ & & significant \\
\hline R. Wilson et al., 1971 & Irritability & 95 & 73 & $0-6$ years & & & & & $\mathrm{Sig}$ & ficant \\
\hline $\begin{array}{l}\text { H.H. Goldsmith, } \\
\text { I.I. Gottesman, } 1981\end{array}$ & $\begin{array}{l}\text { Irritability } \\
\text { Fearfulness }\end{array}$ & $\begin{array}{r}72- \\
91\end{array}$ & $\begin{array}{r}35- \\
50\end{array}$ & 4 years & & & & & $\begin{array}{l}.45 \\
.36\end{array}$ & $\begin{array}{l}.17^{*} \\
.21^{*}\end{array}$ \\
\hline $\begin{array}{l}\text { R.Plomin, T.T.Foch, } \\
1980\end{array}$ & Aggressivity & $\begin{array}{r}40- \\
51\end{array}$ & $\begin{array}{r}28- \\
32\end{array}$ & 7 years & & & & & $\begin{array}{l}.38 \\
.43\end{array}$ & $\begin{array}{l}.44 \\
.20^{*}\end{array}$ \\
\hline S. Scarr, 1966 & $\begin{array}{l}\text { Anxiety } \\
\text { Worry }\end{array}$ & 24 & 28 & $6-10$ years & & & .56 & $.03^{\star}$ & & \\
\hline $\begin{array}{l}\text { A.P. Matheny, } \\
\text { A. Dolan, } 1980\end{array}$ & Emotionality & 68 & 37 & $7-10$ years & & & & & .45 & $-.11^{*}$ \\
\hline
\end{tabular}

Figure 2

English translation of Table 45 from Ravich-Shcherbo (1998).

.52). One notable exception concerned creativity for which $\mathrm{MZ}$ and $\mathrm{DZ}$ correlations were .61 and .50 , respectively. It was suggested that the dimension of creativity may differ in Russia, given that schools do not foster individual expression.

ARTS was initiated in 1994. It has enabled investigation of same-sex adult twins residing in Moscow and the surrounding metropolitan area. Participants were identified as part of the Moscow Twin Registry, established by compiling information from medical clinics in Moscow government districts. Information was first sought in 1960 . Twins range in age from one to seventyfive years and do not overlap with those in the longitudinal project. The first two studies summarised below were facilitated by this source.

Dr. Keith Whitfield, Associate Professor of Biobehavioral Health at Pennsylvania State University, has participated in two ARTS-based projects (Saudino, Gagne, Grant, Iboutolina, Marytuina, Ravich-Shcherbo, \& Whitfield, 1999; Whitfield, Grant, Ravich-Shcherbo, Marytuina, \& Iboutolina, 1999). Both studies involved international collaboration.

Whitfield was intrigued by these opportunities because environmental factors in Russia differ dramatically from those of the western nations that have produced most twin and adoption studies. He posed two competing hypotheses: (1) the communist regime could have reduced environmental variation among its citizens, (2) or the changed political climate as of 1989 may have enhanced variability with respect to resources and earnings.

The first study was an analysis of genetic and environmental influences on personality. Measures included neuroticism and extraversion scales from the Eysenck Personality Inventory (short form) and monotony avoidance and impulsivity scales from the Karolinska Scale of Personality. Items were presented to participants in Russian. Heritability estimates were consistent with those in reports from western cultures (.49 to .59), as were findings of negligible shared environmental effects. Thus, acknowledged cultural differences failed to affect individual personality differences in a meaningful or lasting way.

The second study examined genetic and environmental influences on forced cates the maximum amount of air that can be expelled in a given number of seconds during a forced vital capacity expiratory volume (FEV). FEV indi- determination (On-line Medical Dictionary, 1995-1998). Twins' height and smoking history were also obtained. Findings are summarised in a personal communication from Whitfield:

Working with my Russian collaborators provided a fascinating insight into a different culture. My experience fortified my ideas that behavior genetic studies across cultures would pick up on the power of the environment to influence development. One of the examples we found was for a measure of forced expiratory volume (FEV). FEV has been found to be a strong predictor of life expectancy in numerous studies and health, in general. Shared environmental factors accounted for a significant portion of the individual variability in FEV, unlike studies done in Sweden with a comparable cohort. We attribute this to the past influence of communism on health and cultural norms relevant to smoking. Even though we controlled for smoking, the prevalence of smoking among Russians makes the environment a cause, as well.

Twin research has also found a welcome home in Russia's space program. Twins Alexander and Andrew Fingelkurts (whom I profile below) were associated with the State Scientific Centre of the Russian Federation - Institute of Medical and Biological Problems, in Moscow, from 1990 to 1993 . They were part of a group investigating brain processes of Russian cosmonauts. The project used twins to study (1) individual differences in adaptive responses to factors of simulated microgravity conditions and (2) heritability of brain dynamics and personal characteristics during intense experimental operators' activity and during sleep deprivation under simulated flight conditions. A comparative study of mutation rates between experienced cosmonauts and unexposed Russian twins has also been undertaken by Canadian researchers (Khaidakov, Curry, Walsh, Mortimer, \& Glickman 1999).

\section{Twin Festivals}

I have been invited to two twin festivals. A March, 1991 letter from Tamara Morozova introduced the Leningrad "I and You" Twins Club and plans for future twin research. Posters and placards announcing the Second Twins International Festival were also included. A November, 1998 letter from Anatoly Vasjutinsky described activities 
and initiatives of the Club of St. Petersburg Twins, founded in 1995. I could not attend either event, but have received information from Russian twins (A. \& A. Fingelkurts).

The two festivals these twins attended were held in Moscow so were not the same as those mentioned above. The first included "competitions” for within-pair similarity. MZ twins competed across activities (e.g., dancing, drawing and choosing) to determine the most behaviorally identical pair. Winners later participated in a grand show held later at the Rossiya Hall and were invited to visit the United States. The second festival recognised the one-year anniversary of the twins' association. It included a scientific program, as well as various forms of entertainment.

\section{What Lies Ahead}

Colleagues credit Dr. Inna V. RavichShcherbo with rebuilding psychogenetics and twin research programs in Russia. Doctoral students are continuing her tradition via dissertations on twins' speech development, historical trends in Russian psychogenetics and other issues. Another book on twin research (The Nature of Individual Differences: A Study of Twins, by N.F. Talyzina and colleagues) appeared in 1991. More seasoned investigators are working toward a center dedicated to twin studies. Psychogenetics has become an obligatory discipline in the State Standard of Higher and Professional Education in psychology. The "Culture" television channel is producing a segment on psychogenetics and twin studies. People are growing increasingly receptive to genetic explanations of behavior (although residual effects of the environmentalist perspective linger). Much progress has been made, but continuity of empirical work is uncertain.

Desite many reasons for optimism, some worry that no single individual or institute will emerge to nurture RavichShcherbo's contributions toward grander goals. Born in Voronezh in 1927, Ravich-Shcherbo is now seventyfour years of age. She has a daughter, Natasha Vasilenko, who works in polymer chemistry, and a son, Vladimir Krever, who works in biodiversity (World Wide Fund for Nature). She also has five grandchildren and two great-grandchildren. Given the limited available resources, she admits that "these days it is hard for us to do such [twin] studies." Another difficulty may be the recent dismantling of Russia's twelve-year National Human Genome Project and the potential effects of this decision on related research (Pokrovsky \& Allakhverdov, 2001).

International collaborations dedicated to further developing the longitudinal twin study, Russian Twin Registry and ARTS should be encouraged. Organising additional twins' festivals and celebrations, and establishing parents' and twins' clubs are crucial at the current juncture. Reviving 1950s's special services for families with multiple birth children would also be beneficial. And ... Moscow or St. Petersburg might prove a splendid venue for a future International Twin Congress ...

\section{Professional and Personal Portraits of Russian Twins: Drs. Andrew A. and Alexander A. Fingelkurts}

I have never met Drs. Andrew A. and Alexander (Alex) A. Fingelkurts, but I know them well. These thirty-twoyear-old, Russian-born MZ twins are psychophysiologists at the Laboratory of Computational Engineering and Centre for Computational Science and Engineering, at Helsinki University of Technology, in Finland. In the spring, 2001 they had contacted my colleague, Dr. Richard Lippa, for information about his twin studies on gender identity and development. Knowing I would be visiting Russia that summer, Lippa put us in touch and we have corresponded about twins and twin research ever since. We just missed meeting in Moscow because my day of arrival was their day of departure.

Alex and Andrew were born on November 23, 1969 in the city of Krasnador, the capital of the Krasnador territory near the Black Sea. Alex was

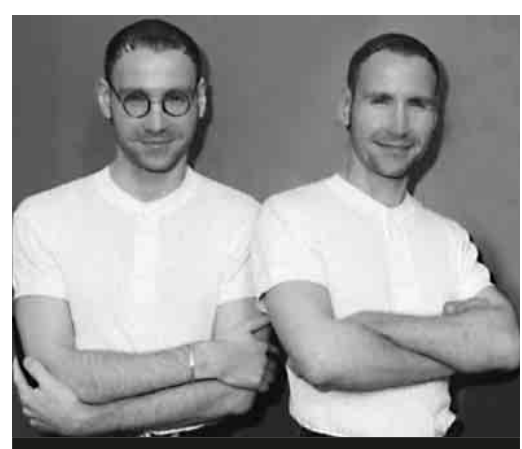

Figure 3

Drs. Alexander A. (left) and Andrew A. Fingelkurts.

first born and the larger of the two, but both twins had very respectable birth weights (3,900 grams and 3,600 grams, respectively). Currently, they are separated by only 5 kilograms (11 pounds) and 4 centimeters (1.50 inches), with Alex maintaining the physical edge. Responses to Nichols \& Bilbro's (1966) physical resemblance form were consistent with $M Z$ twinning at the highest certainty level.

Alex and Andrew's common second name (Alexandrovich) is their father's first name, a Russian custom for naming sons and daughters. They explained that Dr. Ravich-Shcherbo's middle initial (V.) stands for Vladimirovna, so her father's first name was Vladimir. They have no other brothers or sisters.

The twins' father is an engineer by training, but now works in public administration for the Krasnador city region. Their mother graduated from high school before becoming a hairdresser. Her talent was apparently transmitted to her twins whose hair style creations have been exhibited in fashion shows. They crafted a style called "New Romanticism" for an event honoring the 19th century Russian poet, Alexander S. Pushkin. 
Their artistic flair is also expressed in paintings, original in both style and method; more will be said about that momentarily.

Alex and Andrew are individually impressive and collectively dazzling. Each is an accomplished academic with numerous publications, presentations, memberships, honors and awards. Each is a professional painter with a style common to just two. Each recalls interests in human intellectual functioning and drawing emerging as early as age seven. As MZ co-twins, they exemplify conclusions from twin studies of intelligence and achievement showing genetic effects on trait-relevant measures (McGue, Bouchard, Iacono, \& Lykken, 1993; Chambers, Hewitt \& Fulker, 2000). Their current academic passion (the failure of $\mathrm{MZ}$ male twins to realise their potential giftedness), is approached with the same extraordinary zeal. Adding to their interest in human behavior (and our interest in them) is that Alex is left-handed and Andrew is righthanded, although laboratory studies suggest a reverse pattern! Thus, these twins are magnificent sources of information and ideas concerning human cognition, personality, sociability and productivity.

The twins' talents are captured in a single resume accessible from their shared web site (http://www.lce.hut. $\mathrm{fi} /$ fintw1). It is a fascinating read, not just for the scientific accomplishments, but for the oneness of effort and credit that fill each page. Both twins names appear at the top, yet the bundling of two careers in a single package is not immediately obvious. The document's duality is understated, evident only by the use of plural nouns when single forms are expected: "Objective: Ph.D. researchers;" "1987-1989: Privates, USSR Infantry," and first name labels (placed in parentheses) when such details seem extraneous: "Nov. 1998: Successfully defended Ph.D. dissertations: 'Time-spatial organization of human EEG segment's structure' (Andrew), 'Some regularities of human EEG spectral pattern dynamics during cognitive activity' (Alexander)." Two email addresses are also listed, with user names differing by one digit (1 vs. 2 , corresponding to order of birth). It is a stunning economy of effort if one considers that the twins' individual resumes would be virtually identical to the shared one. I found this so fascinating that I pursued the matter with the twins themselves. Their response was a rare glimpse into the subtle psychological aspects of twinship that are often missed. (Note: All written comments were signed "Andrew \& Alex" or, more simply, "A \& A"):

It is a very practical decision - since we have the same records, achievements and dates it is rational to make one CV. Another reason [for doing so] is that when we do not stress that we are identical twins then, very often, people perceive our documents [to be] documents of the same person.

This counterintuitive comeback is well reasoned. Logical singleton minds might suppose that a pair's common vita suggests two individuals presenting as one. Alex and Andrew maintain the opposite, namely that separate papers paint an impression of one person with vitas to spare. The single document with two names preserves the twins, as well as the twinship.

The Fingelkurts's publication and presentation list is an especially interesting feature of their resume. It boasts 15 publications, 7 manuscripts (in press, under review or in preparation), and 21 conference abstracts. All entries bore both twins' names with four exceptions: the two Ph.D. dissertations and two student presentations. All papers, but two, and all abstracts, but three, were co-authored with other investigators, no doubt reflecting the twins' collaborative work situation. Still, I wondered if the twin' authorship would show balanced ordering. Counting revealed that Alex preceded Andrew on 8 papers and 11 abstracts, while Andrew preceded Alex on 12 papers and 8 abstracts. The final tally was 19 (Alex) and 20 (Andrew)! I was reminded of Von Bracken's (1934) marvelous experiments showing greater equality in output by MZ than DZ cotwins when working in close proximity. Again, the twins' sharp insight resolved the question of whether authorships were decided by earning credit, "taking turns" or tossing coins:

This is very simple. Although we are working in the same branch of neuroscience, each of us has his own specialty. On everything associated with spectral descriptions - Alex is first; on everything associated with functional relations of different corti- cal areas - Andrew is first. In other articles, whoever generates the idea is first author. We never have problems with that.

Studying these words, it seems that what appeared as a deliberate decision (i.e., maintaining publication/presentation equality) was not that at all. It is more likely that equality flowed naturally from according greater credit to the rightful owner, a role each twin fills about half the time. Thus, the twin's matched abilities and motivations form the core of their similar productivity.

Why did Alex and Andrew choose to work in Finland? The economic situation for Russian scientists has been poor for some time. With the 1991 dissolution of the Soviet Union, many scientists sought employment abroad (Stone, 1991). Some improvements have occurred, owing to efforts by the International Science Foundation and other organisations supporting research opportunities. However, serious obstacles remain in the form of antiquated equipment and limited funding initiatives. Alex and Andrew faced the additional hurdle of finding an academic residence for two. The Helsinki University of Technology proved an acceptable compromise for several reasons. Its close physical proximity to Russia allowed the twins to maintain research relations with colleagues at the Moscow Brain Research Group, headed by Prof. Alexander Kaplan. It also offered positions to both twins, a situation seemingly difficult to come by.

Are joint academic appointments more easily found by MZ twins than by spouses? Alex and Andrew are the third set of MZ twins I know who secured positions in the same department and academic institution. David and Dean Kopsell, MZ twins from Hebron, Illinois, who participated in my dissertation research when they were nine, have a similar story to tell. Upon receiving doctoral degrees in horticulture from the University of Georgia, they became assistant professors in the University of New Hampshire's Department of Plant Biology (University of New Hampshire Magazine, 2000). Like their Russian counterparts, each twin pursued his own research specialty: David integrated research findings into educational programs and Dean investigated how plants use nutrients more 
efficiently. (David recently left New Hampshire to teach at a small college in rural Illinois.) Twins in a third set are from my campus, California State University, Fullerton. Professors. Hallie Yapp Slowik and Ruth Yapp Edwards are faculty members in the Elementary Education Department.

I am unaware of data comparing twin-twin vs. spouse-spouse professional placements, but the former may prove a better investment. First, MZ twins' matched abilities and personalities probably make them better qualified, on average, for similar positions. (MZ twin correlations exceed assortative mating coefficients for most behavioral traits (Plomin, DeFries, McClearn, \& McGuffin, 2001). Departments and laboratories might, thus, expect greater productivity from twins. Second, MZ twins' extraordinary closeness and cooperation reduce their chances of separation or "divorce," relative to marital partners, in the wake of within-pair dissent. Finally, MZ twins' intrinsic interest might make them more appealing to departments, owing to attention from the community and, conceivably, funding agencies and grant reviewers. $\mathrm{MZ}$ twins are often singled out at amateur and elite sporting events. Physical appearance matters more in athletics where it is part of the performance, than in academics where it is not. However, MZ twin college presidents, Harold Shapiro (Princeton University; he retired in June, 2001) and Bernard Shapiro (McGill University) and academics, Claude Steele (Psychology Department, Stanford University) and Shelby Steele (Race Relations, Hoover Institute) possibly gained some notoriety as twins, over and beyond what they could have accrued as non-twins (see Watters, 1995; Segal, 2000).

Twinship may also assist the Fingelkurts's careers:

We cannot say that we feel we are very special - this is more the feeling of others when they see us or communicate with us. But, of course, twinship is very influential on people. We always feel that people try to listen to us and follow our advice. We are always the leaders.

The foregoing ideas surrounding twins' achievements and occupational attainments await empirical testing. However, if the Fingelkurts's thesis is

correct (i.e., talented $\mathrm{MZ}$ male twins are relatively rare), then twins' vs. spouses' joint scholarship will be hard to compare.

Perhaps MZ twins' close emotional connection, more than their matched talents, is what draws others to them. Studying Alex and Andrew's social relations is another great journey on the "twinship enterprise." They express the highest levels of ease and satisfaction in each other's company. The bond between some spouses, best friends and non-twin siblings may approach, or even match, this level of relatedness; however, I suspect it would be confined to specific contexts. In contrast, the attachment between $\mathrm{MZ}$ twins like Alex and Andrew seems to typify most areas of their shared experience:

We feel very comfortable being twins. We live in peace and never have conflicts. We have common interests and preferences, and we buy the same clothes. We have the same friends. But we can have different opinions on scientific questions - so sometimes we have arguments on scientific problems. Although we like to be twins, we are aware of many problems of twins' lives and attitudes of others toward twins (most of all it concerns personal life). But because we are conscious of it, we haven't any psychological complexes here.

The twins' relations seem able to weather even the fiercest of intellectual storms. I wondered if the spirit of their artistic lives paralleled that of their scientific ones. A different rendering of the same picture emerged, unimaginable to many, but inspiring to all:

\begin{abstract}
We always draw the same work together - this always fascinates our friends, but for us this is very natural and ordinary. However, this does not mean that we divide the painting into two parts. Each of us uses the whole space, and later it is difficult to say who drew what! Actually, we tried to draw with someone else, but realized this was impossible because another person always has different feelings and perceptions which are not coincident with ours.
\end{abstract}

The twins' artistic accolades are dispensed in a varied version of their scientific ones: "We have a very good system for signing our names on the paintings: Fingelkurts A \& A." This approach to artistic creations reminded me of former MZ female twin students

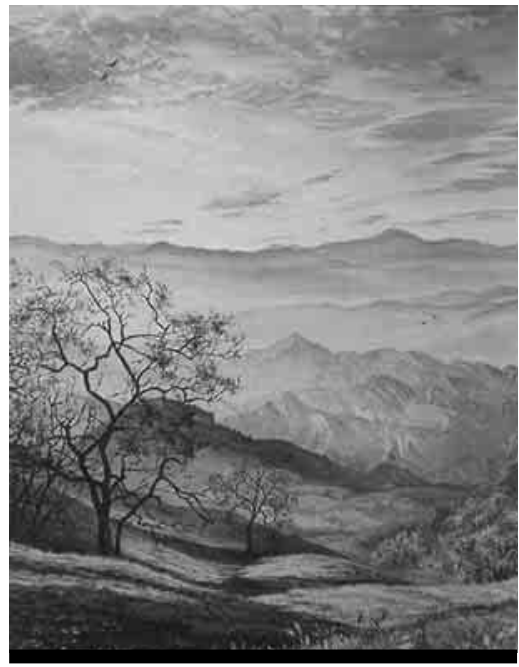

Figure 4

Original painting by A. \& A. Fingelkurts.

who recorded class notes in each other's notebooks during lecture. It is certain that neither recalled the scribbler's identity when studying for examinations, but it probably did not matter.

Running through A \& A's comments are allusions to mechanisms underlying their collaborative compatibility: matched feelings, attitudes, responses and perceptions - a kind of coordination without consciousness. It is a situation that many desire, but which few truly achieve. Could this be the best part of being twins? I asked them to comment:

This question is difficult and the answer will depend on the side to which one looks. If we think about the main influence on our personality, then we can say that constantly being together creates in us a huge tolerance of people's natures. This means that we never react negatively or aggressively to anyone's deviations and peculiarities. And, as a result of that, we have an enormous number of friends. Many of our friends think is it very cool to be twins because you are never alone.

Without interrupting their train of thought, Alex and Andrew next described a curious consequence of spending uninterrupted time with someone, namely loneliness:

But in reality, it [twins never feeling alone] is not true, at least for us. When we are only two - we feel lonely because we need someone with whom to communicate. When we are only two we never communicate between each other because we haven't the topic 
for conversation (all reactions and attitudes are known in advance!). So we always need someone else for communication. But we are aware that our experience of 'lonely' is quite different and distant from that of singletons.

This is not an isolated observation, but one that seems central to MZ twins' social experience. In fact, it replayed a conversation I had overheard several months earlier. MZ twin teenagers pleaded with their reluctant parent to accompany them on a walk. "Please come with us, we don't want to be alone!" Of course, they would not have been strictly by themselves, but like Alex and Andrew, sought stimulation from outside the pair.

I suspect that comfort in each other's company is what distinguishes twins' loneliness from that of others. In their thirty-two years, Alex and Andrew have never been separated for longer than a day at a time. "It feels $\mathrm{OK}$ when you know exactly what is going on. However, if one is absent more than it was agreed then the other one feels physically very bad."

Interviews with Alex and Andrew occurred as a steady stream of e-mailed questions and answers. It was an exhilarating experience, like having clearance to listen in on a classified conversation. Many twins may claim tacit understanding of what was said, but attaching words to feelings is the hard part. Alex and Andrew are masters at this task.

Here is their personal tribute to Dr. Inna V. Ravich-Shcherbo whom they know well:

These words are in appreciation of Inna V. Ravich-Shcherbo's career: Inna Ravich-Shcherbo, Ph.D. is well known in Russia for her many pioneering contributions to psychogenetics (behavioral genetics in the West). Tragic events of the 1930s interrupted the existence of psychogenetics in Russia. Its re-emergence in the late 1960s - early 1970 s coincided with the1972 establishment of a laboratory for investigating the hereditary basis of individual psychological and psychophysiological characteristics. This laboratory is now the Laboratory of Developmental Psychogenetics at the Psychological Institute of the Russian Academy of Education. It's director since 1972 has been Inna V. RavichShcherbo, a position she held until the end of 1993.

Today Inna V. Ravich-Shcherbo is senior researcher at the Psychological Institute of the Russian Academy of Education. Since 1982 she has given lectures on psychogenetics to the Psychological Faculty at the Moscow State University (MSU). In 1982, MSU was the only Soviet University to offer such a course in psychogenetics. Later, as a consequence of Dr. Ravich-

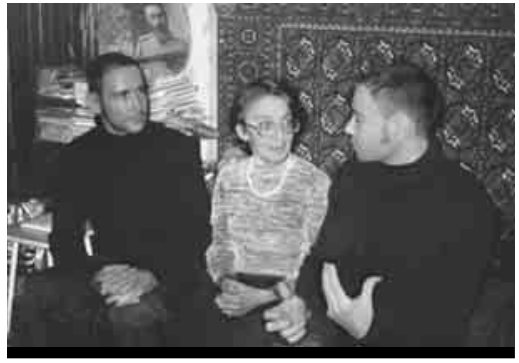

Figure 5

Drs. Alexander A. Fingelkurts (left), Inna V.

Ravich-Shcherbo and Andrew A. Fingelkurts.

Shcherbo's intense activities, the psychogenetics course was approved by the State Educational Committee of the Russian Federation. It is now mandatory for all psychology students.

Dr. Ravich-Shcherbo is the author of 110 articles and editor of the first Russian language monograph on psychogenetics entitled, The Role of Heredity and Environment in the Organization of Human Individuality (1988), Moskva: Pedagogika. She is editor and co-author of the first Russian textbooks on this subject, Psychogenetics (1999). She was also the organiser of the Twins Registry in Russia and the Twins Club in Moscow. Now, at age seventy-four, Dr. Inna V. Ravich-Shcherbo is still very active. Communication with her (as always) is a real celebration of intelligence, truthfulness and optimism.

\section{From Moscow to the Midwest: Max and Andy}

Last year, author Daniel Jussim called with a dual request: He was writing a book about twins targeted to young audiences - would I consent to an interview, and could I furnish a photograph of $\mathrm{MZ}$ twins reared apart? I answered affirmatively to both those questions. Double Take: The Story of Twins appeared about a year later. The book's lovely layout, engaging tales and pleasing portraits promise a wonderful read for people of all ages. The story of Russian twins, Max and Andy, is particularly touching and one that will be remembered for some time. Here it is.

In 1991, Max and Andy were living as orphans in a home outside Moscow. These three-year-olds were part of a rare
$\mathrm{MZ}$ twin group whose physical handicap was linked to unusual adversities in prenatal life. The umbilical cord had wrapped around their legs, blocking circulation to the limbs and causing them to gangrene. Following birth, Max and Andy underwent double and single amputations, respectively. They learned to crawl and hop, given that doctors could not furnish them with artificial limbs.

The twins' fate took a wonderful turn when Ron Greenfield, of Illinois, became aware of their situation. His empathy flowed naturally from years of wartime service, an experience that left him without his left leg. Greenfield arranged to adopt the twins, immediately outfitting them with prostheses so they could share his joy of outdoor sports.

\section{Note}

I discussed congenital gangrene in MZ twins in an earlier issue of Twin Research (Segal, 2000b). In this case, the pair was female and only one twin was affected. A blood clot was suspected to have lodged in her upper thigh, denying blood to that region and preventing her right leg from growing. When the twins were examined eighteen years ago, their physician estimated that 85 cases (including twins and non-twins) had been reported world-wide. The proportion of twins among these cases is not currently known. Additional data on the frequency and possible prevention of congenital gangrene in twin and nontwin infants would be welcome. 


\section{Moscow Summer School Series: Twin Lectures and Twin Runs}

The first in a series of three Moscow Summer School lectures took place in Zvenigorod, Russia, between June 1926, 2001, just prior to the International Twin Congress, in London. The program was organised by Dr. Marina Butovskaya (Institute of Ethnology and Anthropology, Russian Academy of Sciences, Moscow and Russian State University for the Humanities, Moscow) and Dr. Frank Salter (Max Plank Institute, Andechs and Ludwig Maximilien University, Munich). The venue was a conference center and resort for Russian Academy of Sciences members and their families. It could be reached from Moscow by car in approximately two hours time. This was an exciting opportunity for Russian students and international faculty to build professional and personal relationships.

As a lecturer in this program, I was encouraged to be available to students on an informal basis after scheduled talks ended. One night I gathered with students in the lobby café to review material from my twin lecture and to share photographs of twin children and adults. I, in turn, heard a great deal about Russian twins and twin research, especially studies conducted by Dr. Ravich-Shcherbo. I listened to a captivating tale about reared apart female twins from a southern region. (Note: Russian laws respect the privacy of adoption so finding twins reared apart through social services would not be possible. Furthermore, few parents would acknowledge having adopted a child, so public requests for reared apart twins would probably prove futile.) I also mastered the Russian words for MZ ("bliz-nit-zi") and DZ twins ("dvoi-niash-ki"), but not the accents! One evening, when presentations had not been scheduled, guests watched videotaped programs on twins I had brought from the United States. These popular presentations were a great complement to the formal lectures - anyone working with twins knows that seeing multiples in action lends substance and meaning to scientific material. The visit to Russia was a great reminder that appreciation for twins and twin research is universal, and that those of us who do it will find friends everywhere.

Twin work continued early the next morning and every morning of my stay in Russia, but not in the conventional way. A fellow lecturer, Dr. Linda Gottfredson, from the University of Delaware, was accompanied by her nineteen-year-old MZ twin daughters, Nina and Lisa. The twins were avid athletes and the three of us enjoyed a succession of runs through the streets of Moscow, the roads of Zvenigorod and, eventually, the riverbanks of St. Petersburg where we traveled once the conference ended. Spending extended informal time with $\mathrm{MZ}$ twins was a rare treat because twins disclose so much about human behavior just by being themselves. Nina and Lisa's synchronised running styles, vocal rhythms and spirited personalities were fascinating phenotypes. Once again, I was aware that making sense of such coordinated development would hardly be possible without reference to the wealth of available behavioral genetic data. Even twin studies' harshest critics may have been persuaded had they joined one of our twenty-minute jaunts.

A St. Petersburg highlight was a tour of Dostoevsky's neighborhood that included a visit to the "murder scene" in Crime and Punishment. The guide also praised Dostoevsky's less celebrated second novel, The Double, which tracks the entwined lives of Golyadkin, a civil servant, and his exact duplicate who garners status and favor at Golyadkin's expense. It is unclear if "the double" exists or represents an alternative side to the protagonist's personality, a dilemma readers still debate. The themes of duality and identity make this work attractive to anyone with twin interests.

\section{Final Thoughts: Reflections and Recognition}

More than any of my other contributions to News, Views and Comments, the present piece became an amazing process of discovery, regret and respect. Such emotions are foreseeable consequences of reliving the birth, demise and resurrection of a rich scientific tradition.

I am grateful for the assistance of my co-author, Irina N. Senina, a California State University sophomore and aspiring neurobiological investigator from Bryansk, a small city near Moscow. Special thanks are also due to Elena Grigorenko (Yale University), Keith Whitfield (Pennsylvania State University), Kimberly Saudino (Boston University) and Andrew and Alexander Fingelkurts (Helsinki University of Technology). Elizaveta (Liza) Bojko, a student at the Russian State University, delivered a copy of my book (Segal, 2000a) and a note to Dr. RavichShcherbo; I only regret that I was unable to do so myself. I am indebted to Dr. Ravich-Shcherbo's daughter, Natasha Vasilenko, for managing the e-mails and faxes that passed between her mother and me. My deepest appreciation goes to Dr. Ravich-Shcherbo for graciously replying to the myriad of questions placed before her and for sharing her reflections with those who care. 


\section{References}

Allen, G. (1978). Bronson price: 1905-1978. In memoriam. Acta Geneticae Medicae et Gemellologiae, 27, 95-96.

$B B C$ on-line. Conjoined twins. (www. modcult.brown.edu/students/angell/twin soperation.html).

Chambers, M. L., Hewitt, J. K., \& Fulker, D. W. (2000). Variation in academic achievement and IQ in twin pairs. Intelligence (in press).

Davis Chiropractic Center on-line. (www. davis-chiro.com/masdas.html).

Egorova, M. S. (1987). Genetic factors in interpersonal variance of field dependence - independent indicators. Activitas Nervosa Superior, 29, 19-22.

Finkelkurts, A., \& A. (200I). Personal communication.

Gardner, M. (1957). Fad and fallacies in the name of science. New York: Dover Books.

Gavrish, N. V., Malykh, S. B., \& Meshkova (1993). Sex differences in EEG spectral characteristics of 6-7-year-old children. Human Physiology, 19, 26I-265.

Grigorenko, E. L., LaBuda, M. C., \& Carter, A. S. (1992). Similarity in general cognitive ability, creativity, and cognitive style in a sample of adolescent Russian twins. Acta Geneticae Medicae et Gemellologiae, $4 I, 65-72$.

Grigorenko, E., \& Ravich-Shcherbo, I.V. (1997). Russian psychogenetics: Sketches for the portrait. In E. L. Grigorenko, P. M. Ruzgis, \& R. J. Sternberg (Eds.), Psychology in Russia: Past, present, and future (pp. 84-121). Commack, NY: Nova Science Publishers, Inc.

Halperin, S. L. (1975). A twin study of intelligence in Russia. Behavior Genetics, 5, 83-86.

Jussim, D. (200I). Double take: The story of twins. N.Y.:Viking.

Khaidakov, M., Curry, J.,Walsh, D., Mortimer, A., \& Glickman, B. W. (1999). Study on genotoxic effects of the space environment: a comparison between experienced cosmonauts and unexposed Russian twins. Mutation Research, 430, 337-342.
Levit, S. G. (1935). Twin investigations in the U.S.S.R. Character and Personality, 3, 188-193.

Malykh, S. B. Egorova, M S., \& P'iankova, S. D. (1993). The etiology of individual differences in cognitive strategy. Journal of Russian and East European Psychology, 3I, 47-55.

McGue, M., Bouchard, T. J., Jr., lacono, W. G., \& Lykken, D.T. (1993). Behavioral genetics of cognitive ability: A life-span perspective. In R. Plomin \& G. E. McClearn (Eds.) Nature, nurture and psychology (pp. 59-76). Washington, D.C.: American Psychological Association Press.

Meshkova, T. A. (1992). Laterality effects in twins. Acta Geneticae Medicae et Gemellologiae, 4I, 325-333.

Meshkova, T. A., \& Ravich-Shcherbo, I. V. (1982). Influence of the genotype on the determination of individual featres of the human EEG at rest. In H.-D. Schmidt \& G. Tembrock (Eds.), Evolution and determination of animal and human behaviour (XXII International Congress of Psychology). Amsterdam: North Holland Publishing Co.

Moscow Dentist Enters LLU International Dentist program. Loma Linda University School of Dentistry News. 2 November 2002 (www.llu.edu).

Nichols, R. C., \& Bilbro, W. C. (1966). The diagnosis of twin zygosity. Acta Geneticae et Statistica Medicae, 16, 265-275.

On-line Medical Dictionary (1995-1998). Graylab, UK.

Orekhova, E. V., \& Malykh, S. B. (1997). Age-dependent peculiarities of the readiness potential during performance of simple voluntary movement. Human Physiology, 23, 400-405.

Plomin, R., DeFries, J. C., McClearn, G. E., \& McGuffin, P. (200I). Behavioral genetics (4th ed.). New York:Worth Publishers.

Pokrovsky, V., \& Allakhverdov, A. (200I). Government spurns human genome effort. Science, 294, I26I.

Price, B. (1950). Primary biases in twin studies; A review of prenatal and natal difference-producing factors in monozygotic pairs. American Journal of Human Genetics, 2, 293-352.
Price, B. (1978). Bibliography on of prenatal and natal influences in twins. Acta Geneticae Medicae et Gemellologiae, 27, 97-II3.

Ravich-Shcherbo, I. V. (1988) The role of heredity and environment in the Organization of Human Individuality (in Russian). Moscow: Pedagogika.

Ravich-Shcherbo, I. V. (200I). Personal communication.

Saudino, K. J., Gagne, J. R., Grant, J., Iboutolina, A., Marytuina, T., RavichShcherbo, I., \& Whitfield, K. E. (1999). Genetic and environmental influences on personality in adult Russian twins. International Journal of Behavioral Development, 23, 375-389.

Segal, N. L. (2000a). Entwined Lives: Twins and what they tell us about human behavior. N.Y.: Plume.

Segal, N. L. (2000b). Identical and fraternal: When words mislead. Twin Research, 3, 383-343.

Stone, R. (1991). Cautious optimism, but progress is slow. Science, 294, 974.

Stroganova, T. A. Tsetlin, M. M., Malykh, S. B., \& Malakhovskaya, E. V. (2000). Biological principles of individual differences of children of the second half-year of life: Communication II. The nature of individual difference in temperamental features. Human Physiology, 26, 28I-289.

University of New Hampshire Magazine. (2000). Double take. p. 8.

Talyzina, N. F., Krivtsova, S. V., \& Mukhamatulina, E. A. (I99I). The nature of individual differences: $A$ study of twins. Moskva: MGU.

Vogel, F., \& Motulsky, A. G. (1986). Human genetics: Problems and approaches. Berlin: Springer-Verlag.

Von Bracken, H. (1934). Mutual intimacy in twins. Character and Personality, 2, 293-309.

Watters, E. (1995). Claude Steele has scores to settle. New York Times Magazine, 17 September, pp. 45-47.

Whitfield, K. E., Grant, J., Ravich-Shcherbo, I.V., Marytuina, T., \& Iboutolina, A. (1999). Genetic and environmental influences on forced expiratory volume in midlife: A cross-cultural replication. Experimental Aging Research, 25, 255-265. 